\title{
PREVALENCE AND SEVERITY OF PERIODONTAL DISEASE IN TYPE 2 DIABETES MELLITUS PATIENTS: A CROSS-SECTIONAL STUDY
}

\author{
PREVALENCIA E SEVERIDADE DA DOENÇA PERIODONTAL EM PACIENTES \\ PORTADORES DE DIABETE MELLITUS TIPO 2: UM ESTUDO TRANSVERSAL
}

\section{Micheline Sandini TRENTIN ${ }^{1}$; João Paulo DE CARLI², Michele De Conto FERREIRA ${ }^{3}$; Diego José GAMBIN ${ }^{3}$; Soluete Oliveira da SILVA ${ }^{4}$; Hugo LISBOA}

1. Professor at the School of Dentistry of the University of Passo Fundo, RS, Brazil. PhD in Periodontics by the São Paulo State University, Araraquara, SP, Brazil. tmicheline@ upf.br; 2. PhD in Stomatology by the Pontifical Catholic University, Curitiba, PR, Brazil; 3. Master student in Dentistry Clinics at the University of Passo Fundo, RS, Brazil; 4. Professor at the School of Dentistry of the University of Passo Fundo, RS, Brazil. PhD in Pathology and Stomatology by the Pontifical Catholic University, Porto Alegre, RS, Brazil

\begin{abstract}
This is a cross-sectional clinical study performed with type 2 diabetes mellitus patients and nondiabetic patients, in the city of Passo Fundo, RS, Brazil, which aimed to verify whether periodontal disease is more prevalent in type 2 diabetes mellitus (DM2) patients. The study sample included 275 patients, wherein 117 were type 2 diabetes patients and 158 were non-diabetic patients, who were assessed between the years of 2007 and 2010 . The inclusion criteria of the study were patients older than 35 years with DM2 diagnosed for more than one year through glycemia and glycosylated hemoglobin tests. The same criteria was used for the control group, except for the presence of diabetes. The participants were evaluated by students calibrated for the Periodontal Screening and Recording (PSR) index and through a questionnaire assessing age, gender, oral hygiene conditions, and medications of the patients. Generalized gingivitis was more prevalent in diabetic patients $(p<0.001)$. The level of oral hygiene of the diabetic patients was considered fair and poor $(\mathrm{p}<0.001)$ when compared to the non-diabetic patients. More sextants with periodontal health were observed in non-diabetic patients $(\mathrm{p}<00.1)$ when compared to type 2 diabetes mellitus patients; tooth loss was also greater in DM2 patients. The study allowed concluding that DM2 patients presented higher prevalence of periodontal disease than the control group. The factors that might have influenced these results were systemic condition (DM2), level of oral hygiene, and age, which justifies the high rate of periodontal disease and tooth loss in these individuals.
\end{abstract}

KEYWORDS: Type 2 diabetes mellitus. Periodontitis. Prevalence. PSR.

\section{INTRODUCTION}

Type 2 diabetes mellitus consists of a group of metabolic diseases characterized by hyperglycemia derived from the failure of insulin secretion or action; it is also considered a risk factor for periodontal disease. This factor might be explained by the altered cells and molecules in the periodontal disease caused by hyperglycemia (BHARTI et al., 2013; DAMODAR \& MEHTA, 2018).

Periodontal diseases include a heterogeneous group of immunoinflammatory changes from the host response to bacterial plaque and its products, and they are among the most prevalent oral diseases. They may involve tissues that suffer modifications such as morphological and biochemical changes on the root surface, replacing the junctional and sulcular epithelium for the periodontal pocket epithelium, as well as episodes of conjunctive attachment loss and alveolar bone resorption (SOCRANSKY; HAFFAJEE, 1992; TELES et al., 2014).
Diabetes mellitus is not considered the direct cause of periodontal disease, but rather a systemic factor that provides local conditions for its development, and bacterial plaque is the primary factor for developing periodontal disease (CHANG et al., 2013). However, in patients with DM2 associated with periodontal disease, a negative relationship with quality of life is observed (MOURÃO et al., 2016).

Diabetes mellitus leads individuals to hyperglycemia. This, in turn, modifies cells, tissues and organs, causing the decrease of collagen synthesis and chemotaxis, change in growth factors, increase of apoptosis and oxidative stress, decrease of extracellular matrix, deregulation of cytokines, and salivary changes, which result in periodontal disease among other illnesses (MAURIOBRADORS et al., 2018).

The relationship of diabetes - both types 1 and 2 - with oral and periodontal diseases and its influence on oral pathologies are evident. The most prevalent oral manifestations in diabetes mellitus patients, while not specific to this disease, have their incidence or progression favored by the lack of 
glycemic control. Thus, the maintenance of periodontal tissue health contributes to an improved metabolic control, reducing the need for insulin and the levels of glycosylated hemoglobin (LALLA et al., 2011; DAMODAR; MEHTA, 2018).

Poorly controlled diabetic patients have a higher risk of developing periodontitis than wellcontrolled and non-diabetic patients. Consequently, fairly controlled diabetic patients respond well to treatment, similar to a non-diabetic patient. On the other hand, poorly controlled patients generally present an inexpressive response to treatment, with more postoperative complications and less favorable results in the long term (TSOBGNY-TSAGUE et al., 2018).

Type 2 diabetes mellitus is considered an aggravating factor of periodontal disease and its incidence has been increasing due to several reasons, such as sedentary lifestyle, obesity, increased life expectancy, and higher survival of diabetic patients (ZAMBON et al., 2018, WOOTON, 2018). Thus, further studies are required to assess the correlation between both diseases.

Both periodontitis and type 2 diabetes mellitus are chronic inflammatory diseases that have a multifactorial etiology in common, which is influenced by cytokines in their etiopathogenesis. A recent study stated that hyperglycemia plays a major role in the increase of severity of periodontal disease in diabetic patients (BASHKI et al., 2018). Thus, glycemic control may improve the periodontal condition of such patients, and the opposite is true as well. Thus, the present epidemiological survey is justified for alerting the diabetic population about the control of periodontal disease, because such control will facilitate the maintenance of glycemic levels within an acceptable range.

This research aimed to evaluate the bidirectional relationship between diabetes mellitus and periodontal disease, as well as to identify whether the prevalence and severity of periodontal disease and tooth losses in type 2 diabetes mellitus patients are greater than in non-diabetic patients.

\section{MATERIAL AND METHODS}

The present study was developed in the Diabetes Outpatient Clinic of the School of Medicine, at the Hospital São Vicente de Paulo (AS-FM-HSVP) and the Examination, Screening and Emergency Section of the School of Dentistry of the University of Passo Fundo (SETU-FO-UPF), in the city of Passo Fundo, RS, Brazil, from June 2007 to July 2010 . The study was approved by the Research Ethics Committee of the University of
Passo Fundo (protocol n. 797/2007). The patients were invited to participate in the study, and those who agreed signed an Informed Consent Form (ICF).

Two groups were considered for inclusion in the study: patients with type 2 diabetes mellitus diagnosed more than one year earlier (case group) and non-diabetic patients diagnosed at the time of examination through blood glycemia and glycated hemoglobin tests (control group). The exclusion criteria for the case group were patients younger than 35 years, pregnant women, immunodepressed and irradiated patients, smokers, and complete edentulism in both arches. The same criteria was used for the control group, except for the presence of diabetes.

The cross-sectional research included an experimental group (117 patients with type 2 diabetes examined at the Outpatient Specialty Clinic FM-HSPV) and a control group (158 non-diabetic patients examined at the SETU-FO-UPF), with a total sample of 275 patients. The sample studied was obtained by convenience.

The criteria proposed by the American Diabetes Association in 2013 were used for diagnosing diabetes mellitus. According to fasting glycemia, the individuals were classified in the following categories: Regular patients FPG $<100$ $\mathrm{mg} / \mathrm{dL}$ of blood OGTT $<140 \mathrm{mg} / \mathrm{dL}$; Pre-diabetes FPG $\geq 100$ and $<126$ OGTT $\geq 140$ and $<200$; and Diabetes FPG $\geq 126$ OGTT $\geq 200$. Considering OGTT - Plasma glucose load in the previous $2 \mathrm{~h}$, containing the equivalent of $75 \mathrm{~g}$ of dissolved glucose.

The research participants were evaluated for the presence or absence of periodontal disease through the PSR index and a questionnaire was applied to assess variables such as age, gender, socioeconomic conditions, level of oral hygiene, and medications used. The periodontal clinical evaluation was performed by two examiners previously calibrated for the PSR index, with intraand inter-examiner concordance rate of $90 \%$ and variation of $1 \mathrm{~mm}$ between the readings. The clinical periodontal examination was aided by a mouth mirror and an especially recommended periodontal probe (WHO 621) with a $0.5 \mathrm{~mm}$ diameter ball tip, dark band between 3.5 and 5.5, 8.5 and $11.5 \mathrm{~mm}$, and a light wire, which was specific for the PSR index (PSR; AAP, 1992) and the respective treatment needs (TEKAVEC; TEKAVEC, 1993).

The dental arches were divided into sextants for the periodontal clinical examination. Next, the 
highest code was registered for each sextant and for each patient.

For the clinical examination, the mouth was divided into sextants determined by teeth $18-14,13-$ $23,24-28,38-34,33-43$, and 44-48. The presence of two or more teeth without indication of extraction (e.g., furcation and mobility defects) were prerequisites for sextant examination. The data collected were analyzed by the SPSS 15.0 for Windows $^{\mathrm{TM}}$ software with qualitative research focus, and the statistical analysis was performed by the chi-square test and ANOVA at 5\%, and odds ratio.

\section{RESULTS}

This study showed that most diabetes mellitus patients were older than 50 years and the non-diabetic patients were between 35 and 50 years old. There was homogeneity between genders regarding the presence of diabetes: 53 male patients and 64 female patients (Table 1).

Table 1. Data regarding age and gender of the patients examined, according to the chi-square test at 5\% significance:

\begin{tabular}{|c|c|c|c|c|c|c|c|c|}
\hline \multirow[t]{3}{*}{ Age } & \multicolumn{4}{|c|}{ Diabetes } & \multirow[t]{3}{*}{ Gender } & \multicolumn{3}{|l|}{ Diabetes } \\
\hline & \multicolumn{2}{|l|}{ No } & Yes & Total & & $\overline{\mathrm{No}}$ & Yes & \multirow{2}{*}{$\begin{array}{l}\text {-Total } \\
\text { N \% }\end{array}$} \\
\hline & $\mathrm{N}$ & $\%$ & $\mathrm{~N}$ & & & $\mathrm{~N}$ & $\mathrm{~N}$ & \\
\hline $\begin{array}{l}35 \text { to } 50 \\
\text { years }\end{array}$ & 89 & (72.9) & $33(27.1)$ & $122(100)$ & Male & $59(52.67)$ & $53(47.33)$ & $112(100)$ \\
\hline $\begin{array}{l}\text { More than } \\
50 \text { years }\end{array}$ & 69 & (45.1) & $84(54.9)$ & $153(100)$ & Female & 99 (60.7) & $64(39.3)$ & $163(100)$ \\
\hline Total & 158 & $(57.4)$ & $117(42.5)$ & 275 (100) & Total & $158(57.4)$ & $117(42.4)$ & 275 (100) \\
\hline & & & & $p=0.00$ & & & & \\
\hline
\end{tabular}

Patients between 35 and 50 years old (31) and older than 50 years (83) fit in the mean time of 5-10 years of disease diagnosis. A statistical analysis (chi-square) was also performed for the diagnosis of diabetes and the PSR indexes, showing no significant differences between these data $(\mathrm{p}=0.09)($ Table 2$)$.

Table 2. Age of patients analyzed and time of diabetes diagnosis by the chi-square test at 5\% significance:

\begin{tabular}{lllcl}
\hline Time of diabetes & $(1-5$ years $)$ & $(5-10$ years $)$ & (more than 10 years) & \multicolumn{2}{c}{ Total } \\
& $\mathrm{N} \%$ & $\mathrm{~N} \%$ & $\mathrm{~N}$ & $\mathrm{~N}$
\end{tabular}

\begin{tabular}{lcccccc}
\hline 35-50 years & $9(7.9 \%)$ & 14 & $(12.3 \%)$ & 8 & $(7.0 \%)$ & $31(26.3)$ \\
More than 50 years & $24(21 \%)$ & 35 & $(30.7 \%)$ & 24 & $(21 \%)$ & $83(72.7)$ \\
Total & $33(29 \%)$ & 49 & $(43 \%)$ & 32 & $(28 \%)$ & $\begin{array}{c}114 *(100 \%) \\
p=0.0939\end{array}$ \\
& & & & & &
\end{tabular}

*3 data lost

Most type 2 diabetes mellitus patients presented oral hygiene considered fair to poor $(\mathrm{n}=100)$ when compared to non-diabetic patients $(\mathrm{n}=106) ;(\mathrm{p}=0.001)$, (Table 3$)$.

Table 4 shows that, regarding the upper anterior sextant, there was a prevalence of periodontal health $(\mathrm{n}=58,36.71 \%)$ and gingivitis without retention factor $(n=21,13.29 \%)$ in the nondiabetic patients relative to the diabetic patients. As for severe periodontitis, data were homogeneous in non-diabetic $(n=6,3.81 \%)$ and diabetic $(n=4$, $3.42 \%$ ) patients. The upper posterior sextant showed prevalence of periodontal health and gingivitis in non-diabetic patients relative to the diabetic patients. The right upper posterior sextant showed periodontal health and gingivitis without retention factor and with retention factor in nondiabetic patients (scores 0,1 , and 2 , respectively), 
and severe periodontitis was slightly greater for diabetic patients than non-diabetic ones. In turn, all the absent sextants presented higher prevalence in diabetic individuals than non-diabetic ones. All the sextants analyzed were statistically significant by the chi-square test at $5 \%(\mathrm{p}<0.00)$.

Table 3. Interrelation between the level of oral hygiene and the presence of type 2 diabetes, according to the chi-square test at $5 \%$ significance:

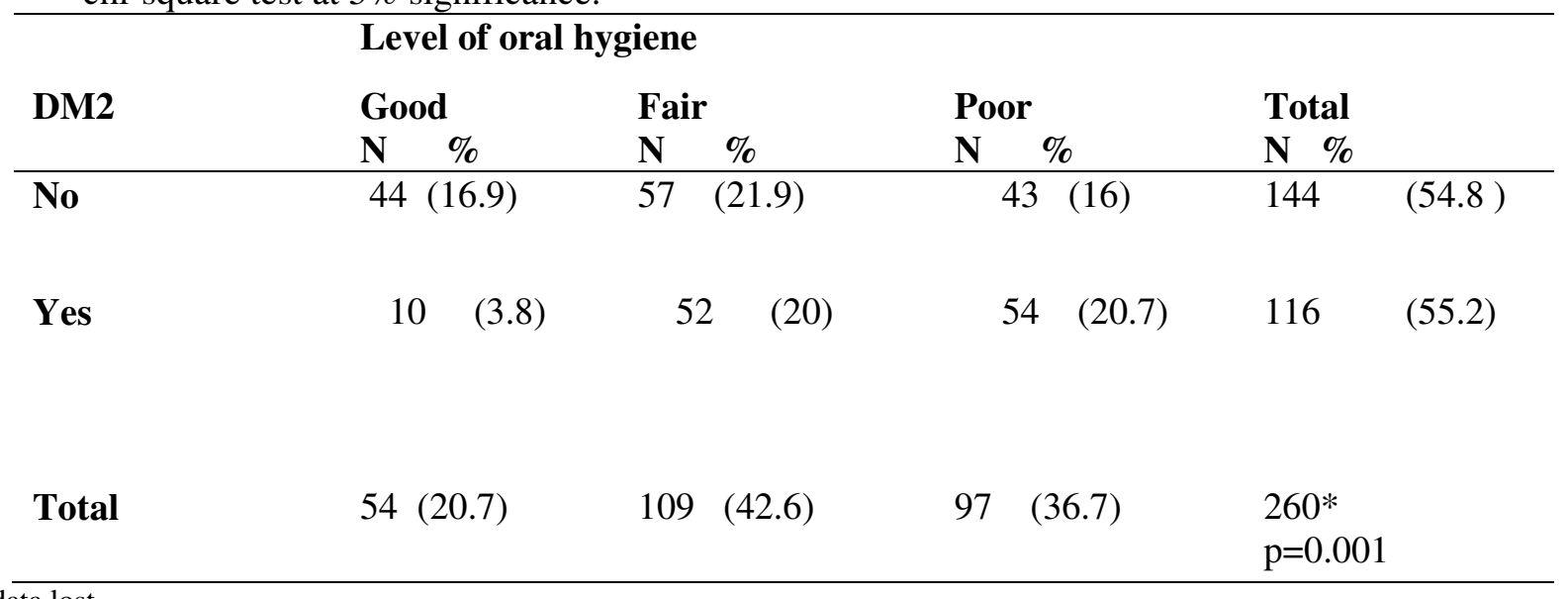

*15 data lost

Table 4. Interrelation between the PSR index in the sextants of the upper arch and presence of type 2 diabetes, according to the chi-square test at $5 \%$ significance:

\begin{tabular}{|c|c|c|c|c|c|c|c|c|}
\hline $\begin{array}{l}\text { Upper } \\
\text { sextant }\end{array}$ & anterior & $\begin{array}{l}\text { Score } \\
\text { 0 }\end{array}$ & $\begin{array}{l}\text { Score } \\
1\end{array}$ & $\begin{array}{l}\text { Score } \\
2\end{array}$ & $\begin{array}{l}\text { Score } \\
3\end{array}$ & $\begin{array}{l}\text { Score } \\
4\end{array}$ & $\begin{array}{l}\text { Score } \\
\text { X }\end{array}$ & Total \\
\hline \multirow{2}{*}{ Diabetes } & No & 58 & 21 & 19 & 11 & 7 & 41 & $157^{*}$ \\
\hline & Yes & 23 & 13 & 12 & 8 & 4 & 57 & 117 \\
\hline Total & & 81 & 34 & 31 & 19 & 11 & 98 & $\begin{array}{l}274 \\
\mathrm{P}=0.000\end{array}$ \\
\hline $\begin{array}{l}\text { Right } \\
\text { posterior s }\end{array}$ & $\begin{array}{l}\text { upper } \\
\text { extant }\end{array}$ & $\begin{array}{l}\text { Score } \\
\text { 0 }\end{array}$ & $\begin{array}{l}\text { Score } \\
1\end{array}$ & $\begin{array}{l}\text { Score } \\
2\end{array}$ & $\begin{array}{l}\text { Score } \\
\mathbf{3}\end{array}$ & $\begin{array}{l}\text { Score } \\
4\end{array}$ & $\begin{array}{l}\text { Score } \\
\text { X }\end{array}$ & Total \\
\hline Diabetes & $\begin{array}{l}\text { No } \\
\text { Yes }\end{array}$ & $\begin{array}{l}46 \\
14\end{array}$ & $\begin{array}{l}23 \\
9\end{array}$ & $\begin{array}{l}26 \\
15\end{array}$ & $\begin{array}{l}14 \\
10\end{array}$ & $\begin{array}{l}4 \\
3\end{array}$ & $\begin{array}{l}44 \\
66\end{array}$ & $\begin{array}{l}157^{*} \\
117\end{array}$ \\
\hline \multicolumn{2}{|l|}{ Total } & 60 & 32 & 41 & 24 & 7 & 110 & $\begin{array}{l}274 \\
\mathrm{P}=0.000\end{array}$ \\
\hline \multicolumn{2}{|c|}{ posterior sextant } & $\begin{array}{l}\text { Score } \\
\mathbf{0}\end{array}$ & $\begin{array}{l}\text { Score } \\
1 \\
\end{array}$ & $\begin{array}{l}\text { Score } \\
2 \\
\end{array}$ & $\begin{array}{l}\text { Score } \\
3 \\
\end{array}$ & $\begin{array}{l}\text { Score } \\
4 \\
\end{array}$ & $\begin{array}{l}\text { Score } \\
\mathrm{X} \\
\end{array}$ & Total \\
\hline \multirow[t]{2}{*}{ Diabetes } & No & 43 & 24 & 29 & 17 & 2 & 38 & $153 * *$ \\
\hline & Yes & 15 & 7 & 15 & 13 & 5 & 62 & 117 \\
\hline Total & & 58 & 31 & 44 & 30 & 7 & 100 & $\begin{array}{l}270 \\
P=0.001\end{array}$ \\
\hline
\end{tabular}

*1 data lost, $* * 4$ data lost

Table 5 showed that the lower anterior sextant had a prevalence of periodontal health, gingivitis without retention factor and with retention factor in the non-diabetic patients relative to the diabetic patients (scores 0,1 , and 2, respectively)$p=0.00$. On the other hand, the absent sextants (score X) and severe periodontitis (score 4) showed higher prevalence in diabetic patients than in nondiabetic ones $(\mathrm{p}<0.00)$. It was also observed that the right lower posterior sextant had a prevalence of periodontal health and gingivitis without retention factor in the non-diabetic patients relative to the diabetic patients $(p<0.00)$. On the other hand, the absent sextants (score $\mathrm{X}$ ) and severe periodontitis (score 4) were significantly higher in diabetic patients than in non-diabetic ones. The left lower posterior sextant also showed a prevalence of periodontal health (score 0), gingivitis without retention factor and with retention factor in the nondiabetic patients relative to the diabetic patients. 
There was a higher prevalence of absent sextants in diabetic patients than in non-diabetic ones. These data presented statistical significance by the chisquare test $(\mathrm{p}=0.001)$.

Table 5. Interrelation between the PSR index in the sextants of the lower arch and presence of type 2 diabetes, according to the chi-square test at 5\% significance:

\begin{tabular}{|c|c|c|c|c|c|c|c|c|}
\hline $\begin{array}{l}\text { Lower } \\
\text { sextant }\end{array}$ & anterior & $\begin{array}{l}\text { Score } \\
0\end{array}$ & $\begin{array}{l}\text { Score } \\
1\end{array}$ & $\begin{array}{l}\text { Score } \\
2\end{array}$ & $\begin{array}{l}\text { Score } \\
3\end{array}$ & $\begin{array}{l}\text { Score } \\
4\end{array}$ & $\begin{array}{l}\text { Score } \\
\text { X }\end{array}$ & Total \\
\hline \multirow[t]{2}{*}{ Diabetes } & $\mathrm{No}$ & 46 & 27 & 46 & 15 & 8 & 16 & 158 \\
\hline & Yes & 19 & 18 & 23 & 12 & 12 & 33 & 117 \\
\hline \multicolumn{2}{|l|}{ Total } & 65 & 45 & 69 & 27 & 20 & 49 & $\begin{array}{l}275 \\
P=0.001\end{array}$ \\
\hline $\begin{array}{l}\text { Right } \\
\text { posterior }\end{array}$ & $\begin{array}{l}\text { lower } \\
\text { extant }\end{array}$ & $\begin{array}{l}\text { Score } \\
0\end{array}$ & $\begin{array}{l}\text { Score } \\
1\end{array}$ & $\begin{array}{l}\text { Score } \\
2\end{array}$ & $\begin{array}{l}\text { Score } \\
3\end{array}$ & $\begin{array}{l}\text { Score } \\
4\end{array}$ & $\begin{array}{l}\text { Score } \\
\text { X }\end{array}$ & Total \\
\hline \multirow[t]{2}{*}{ Diabetes } & No & 36 & 34 & 38 & 9 & 7 & 34 & 158 \\
\hline & Yes & 20 & 15 & 13 & 10 & 3 & 56 & 117 \\
\hline \multicolumn{2}{|l|}{ Total } & 56 & 49 & 51 & 17 & 10 & 89 & $\begin{array}{l}275 \\
P=0.001\end{array}$ \\
\hline \multicolumn{2}{|c|}{ posterior sextant } & $\begin{array}{l}\text { Score } \\
0\end{array}$ & $\begin{array}{l}\text { Score } \\
1\end{array}$ & $\begin{array}{l}\text { Score } \\
2\end{array}$ & $\begin{array}{l}\text { Score } \\
3\end{array}$ & $\begin{array}{l}\text { Score } \\
4\end{array}$ & $\begin{array}{l}\text { Score } \\
\text { X }\end{array}$ & Total \\
\hline Diabetes & No & 32 & 34 & 41 & 9 & 6 & 36 & 158 \\
\hline Total & Yes & $\begin{array}{l}22 \\
54\end{array}$ & $\begin{array}{l}15 \\
49\end{array}$ & $\begin{array}{l}15 \\
56\end{array}$ & $\begin{array}{l}7 \\
16\end{array}$ & $\begin{array}{l}2 \\
8\end{array}$ & $\begin{array}{l}56 \\
92\end{array}$ & $\begin{array}{l}117 \\
275 \\
P=0.000\end{array}$ \\
\hline
\end{tabular}

\section{DISCUSSION}

The bidirectional relationship between systemic diseases such as type 2 diabetes mellitus and periodontal disease has been the topic of numerous clinical researches in periodontal medicine. It also stands out that periodontal disease is the most prevalent oral complication in type 2 diabetes mellitus patients and it is considered the sixth classic diabetes complication (LORENTZ et al., 2009; MOURÃO et al., 2016; GUO et al., 2017). Such affirmations corroborate the findings of the present study, which confirm that generalized gingivitis is more prevalent (score 2) in diabetic patients, along with the fact that such patients presented a lower number of sextants with periodontal health than non-diabetics.

Another significant finding of the present study refer to a higher rate of tooth loss in the group of diabetic patients when compared to the group of non-diabetic patients $(\mathrm{p}<0.001)$. Such observation is supported in the study by PABISCH et al. (2016), which characterized the nanostructure of the alveolar bone of diabetic and non-diabetic mice, finding that the bone mineral particles of diabetic mice are smaller and more disorganized, which potentially influences higher rates of tooth loss. Similar data regarding absent sextants were reported in the literature, which is justified by the number of teeth lost as a strong indicator of periodontal disease (APOORVA et al., 2013).
The present study verified that the level of oral hygiene of diabetic patients was considered fair or poor when compared to non-diabetic patients $(\mathrm{p}=0.001)$. This result complements a recent study (KIM et al., 2018) that reports that the glycosylated hemoglobin levels of 151 patients assessed in Korea were lower after four oral prophylaxis sessions conducted by professionals. It may be suggested that there is a feedback mechanism between periodontal disease and type 2 diabetes mellitus, which justifies the importance of studying the correlation of these diseases.

In this sense, a study reports an association between the markers of metabolic control (tumor necrosis factor) and the severity of inflammation of periodontal tissues in diabetic individuals. Thus, it seems reasonable to suggest that periodontal followup may minimize or neutralize the deleterious effect of a major risk predictor for the progression of periodontal diseases (RIBEIRO et al., 2011). In addition, uncontrolled diabetic patients present higher rates of xerostomia, oral stomatitis, and changes in the Ig-A levels that favor periodontal disease (KAKOEI et al., 2015). Hence, low Ig-A secretion levels suggest a mechanism of susceptibilities to infection in diabetes mellitus patients (OIKAWA et al., 2015).

A recent randomized clinical study (MAURI-OBRADORS et al., 2018) aimed to assess the non-surgical periodontal treatment in relation to glycemic values (hemoglobin A1c or glycated hemoglobin) in type 2 diabetes patients. The study 
analyzed 90 patients, randomly divided into control group (G1) - oral hygiene instruction and supragingival plaque and calculi removal with ultrasound; and experimental group (G2) - oral hygiene instruction, scaling, and root planing with ultrasound and curette. Both groups were assessed 3 and 6 months later. The results indicated that group 2 resulted in a better glycemic status, because of a higher bacterial elimination on the tooth surface. Another study affirms that the glycemic control in uncontrolled patients is essential for monitoring the periodontal disease (TSOBGNY-TSAGUE et al., 2018).

It is known that periodontal disease is more prevalent and severe in diabetic individuals than in non-diabetic ones (LORENTZ et al., 2009; SIMPSON et al., 2015). Type 2 diabetes mellitus patients who are metabolically decompensated may present more gingival inflammation and clinical and bone attachment loss than patients who are controlled or systemically healthy (LORENTZ et al., 2009). Glycemic control may be related to factors such as disease duration, oral hygiene care, and susceptibility to periodontal disease. Periodontal infections, as any other type of infection, may difficult the glycemic control of diabetic patients, because an acute infection predisposes insulin resistance and triggers a state of chronic hyperglycemia (WHANG et al., 2014). Such information corroborate the findings of the present research, especially regarding diabetic patients presenting higher rates of generalized gingivitis, lower levels of oral hygiene, lower number of sextants with periodontal health and higher rates of tooth loss when compared to non-diabetic patients.

This study assessed age, gender, and time of type 2 diabetes mellitus diagnosis and its relation to periodontal disease. Most diabetic patients examined in the research were older than 50 years, while non-diabetic patients were within the age group of 35 to 50 years. From the 275 patients analyzed in the sample, 99 were non-diabetics and women; as for the diabetic patients, 64 were women and 53 were men. However, these data were not statistically significant by the chi-square test at $5 \%$ $(p=0.114)$. In the control group, women sought dental care more frequently than men, which justifies the higher incidence of women in this group. Such considerations are related to another study performed, which showed no statistical difference between diabetes mellitus and the periodontal status associated. Additionally, the authors suggest the need for a periodontal epidemiological approach associating the systemic diseases - in this case diabetes - in order to prevent further complications (APOORVA et al., 2013).

As for the variable of age, the study was homogeneous, verifying 84 diabetic patients older than 50 years, while most of the non-diabetic patients were between 35 and 50 years old (89 individuals). A similar study was observed in Pomerania, which compared type 1 and 2 diabetes patients and non-diabetic patients. This study also developed an odds ratio, which showed that patients older than 50 years presented 3.613 times higher risk to develop type 2 diabetes (KAUR et al., 2009). Recently, a study performed in the city of Vassouras, RJ, Brazil indicated that older patients and decompensated diabetics tend to present higher prevalence of periodontal diseases such as gingivitis and periodontitis (ALMEIDA et al., 2015).

There were no significant differences between gender and time of diabetes diagnosis. Similar results were observed in a study performed in a population of 4343 individuals older than 45 years with periodontal disease, using the weighted multivariate logistic regression analysis. Such study showed that the progression of bone loss as a dependent variable revealed a 2.9 odds ratio of diabetic patients to develop periodontitis, but as for age, the young adults presented higher risk of alveolar bone loss. These results show a relationship between poorly controlled DM2 and severe periodontal disease (TSAI et al., 2002).

In this cross-sectional study, a statistical analysis was performed (chi-square) to assess the time of diabetes diagnosis, according to Table 2, and whether it affected the progression of periodontal disease. There were no significant differences between how long the individual had type 2 diabetes and periodontal disease. All individuals presented similar levels of periodontal disease, regardless of the time of diagnosis. One of the factors that might have influenced these results is the presence of too many absent sextants in diabetic patients, compared to the non-diabetic patients. Such results disagree with a similar study that showed an increase in the severity of periodontal disease with the increase in the duration of diabetes (APOORVA et al., 2013).

The several forms of periodontal diseases have been reasoned in the epidemiology of oral diseases, and the studies developed allow better understanding this process. However, there are limitations for selecting the most adequate epidemiological index. This usually occurs because of the difficulty to establish the meaning of the disease and to better understand the healthperiodontal disease process regarding the clinical parameters (SKUDUTYTE-RYSSTAD et al., 
2014). The present study used the PSR index aiming to assess the presence of periodontal disease. The PSR is a system that allows examining the periodontal structures in a simplified, fast, and effective way for diagnosing and assessing the severity of periodontal disease. This index is an adaptation from the Community Periodontal Index of Treatment Needs (CPITN). It is used to measure gingival bleeding, presence of calculus, and probing depth in each sextant of the oral cavity. The use of this index is justified by the epidemiological character of this research (VAN-DER-VELDEN, 2009).

Type 2 diabetes mellitus patients presented significant differences in the PSR indexes, especially in levels 3 and 4, when compared to nondiabetic individuals, who presented higher prevalence of levels 0,1 , and 2 of the PSR. Such relationship was also verified by (BRANCO-DEALMEIDA et al., 2011). Although scores 1 and 2 were slightly higher for non-diabetic patients (control group), there was also a higher prevalence of partially edentulous individuals in the group of type 2 diabetes patients, and this factor may have affected the results negatively. Previous studies have verified that tooth loss and severity of the periodontal disease in patients are related to type 2 diabetes mellitus (KAUR et al., 2009; MAURIOBRADORS et al., 2018). Similar results were observed, especially affirming that not even glycemic decompensation had interfered with the variable of gingivitis (GOGENENI et al., 2015).

Although the number of patients assessed was high in the present study, the sample was selected by convenience and this may be considered a limitation of the clinical research, affecting the results obtained, which should be analyzed with caution.

In a systematic review and meta-regression analysis, the results affirm that the systemic disease of diabetes mellitus is associated with a high risk of the progression of periodontal disease to periodontitis, especially in adults (NASCIMENTO et al., 2018). GREENBLATT and SALAZAR (2016) affirm that dentists should be updated about the diabetes status of their patients. According to these authors, cases of uncontrolled disease may lead to the loss of dental elements and damage oral function. Therefore, mastication may be impaired, resulting in malnutrition and diabetes complications, as they also affirm.

It is worth noting that the present study was unprecedented for the population group assessed, determining the close relationship between periodontal disease and type 2 diabetes mellitus. Thus, confronting the clinical findings previously discussed with the results of previous studies and considering the cross-sectional design of the present research, it may be affirmed that type 2 diabetes mellitus patients present worse periodontal health conditions and that the oral disease status may affect the evolution of the systemic disease. Hence, it is recommended that dentists perform periodontal treatment in their diabetic patients to prevent the progression of diabetes, also alerting them about the importance of glycemic control so that the periodontal disease will not evolve.

\section{CONCLUSIONS}

Non-diabetic patients presented periodontal health and gingivitis; in turn, diabetic patients presented more absent sextants than non-diabetic patients.

Diabetic patients present higher rates of generalized gingivitis, lower levels of oral hygiene, and lower number of sextants with periodontal health when compared to non-diabetic patients.

Tooth loss is greater in type 2 diabetes mellitus patients.

RESUMO: O presente estudo realizou um estudo clínico transversal em pacientes com diabete mellitus tipo 2 e não diabéticos na cidade de Passo Fundo/RS - Brasil, com o objetivo de verificar se a doença periodontal é mais prevalente nos pacientes com diabetes mellitus tipo 2 (DM2). A amostra do estudo foi composta por 275 pacientes, sendo 117 portadores de diabete tipo 2 e 158 pacientes sem diabete tipo 2, examinados no período de 2007-2010. Os critérios de inclusão neste estudo foram: pacientes com mais de 35 anos de idade e com DM2 diagnosticada há mais de 1 ano através de exames de glicemia e hemoglobina glicosilada. O mesmo critério foi utilizado para o grupo de controle, exceto a diabete. Os participantes foram avaliados por alunos calibrados para o índice Periodontal Screening and Recording (PSR) e através de um questionário avaliando a idade, gênero, condições de higiene bucal e medicamentos utilizados pelos pacientes. A gengivite generalizada foi observada com maior frequência nos portadores de diabete $(\mathrm{p}<0,001)$. $\mathrm{O}$ grau de higiene bucal dos diabéticos foi considerado regular e ruim $(\mathrm{p}<0,001)$ quando comparado ao dos pacientes não diabéticos. Observou-se mais sextantes com saúde periodontal nos pacientes sem diabete $(\mathrm{p}<00,1)$ quando comparados com os pacientes com diabete mellitus tipo 2 e também maior perda dentária nos pacientes com DM2. Conclui-se com o estudo que os pacientes com DM2 apresentaram maior prevalência da doença periodontal quando comparados ao grupo de 
controle. Os fatores que podem ter influenciado esses resultados foram a sua condição sistêmica (DM2), grau de higiene oral e idade dos mesmos, justificando o alto índice de doença periodontal e perda dentária nesses indivíduos.

PALAVRAS-CHAVE: Diabete mellitus tipo 2. Periodontite. Prevalência. PSR.

\section{REFERENCES}

ALMEIDA, B. B; FERREIRA, A. C. R; QUEIROZ, A. P. G; DORNELAS, G. N; COELHO, M. M. S. T. Condições periodontais em portadores de diabetes mellitus antedidos no centro de referência sul fluminense de diabetes e hipertensão de Vassouras-RJ. Braz J Periodontol. v. 25, n. 4, p. 14-23, 2015.

American Diabetes Association. Diabetes Care. 2013; 36(1):S67-S74.

APOORVA, S. M.; SRIDHAR, N.; SUCHETHA, A. Prevalence and severity of periodontal disease in type 2 diabetes mellitus (non-insulin-dependent diabetes mellitus) patients in Bangalore city: An epidemiological study. J Ind Soc Periodontol. v. 17, n. 1, p. 25-29, 2013. https://doi.org/10.4103/0972-124X.107470

BAKSHI D., KAUR G, SINGH D, SAHOTA J, THAKUR A, GROVER S. Estimation of plasma levels of tumor necrosis factor-a, interleukin-4 and 6 in patients with chronic periodontitis and type II diabetes mellitus. $\mathrm{J}$ Contemp Dent Pract, v. 19, n. 2, p. 166-169, 2018. https://doi.org/10.5005/jp-journals-10024-2231

BHARTI, P.; KATAGIWI, S.; NITTA, H.; NAGASAWA, T.; KABAYASHI, H.; TAKUCHI, Y.; IZUMIYANMA, Y.; UCHIMURA, I.; INIUE, S.; IZUNIY Y. Periodontal treatment with topical antibiotics: improves glycemic control in association with elevated serum adiponectin in patients with type 2 diabetes mellitus. Obes Res Clin Pract. v. 7, n. 2, p. 129-138, 2013. https://doi.org/10.1016/j.orcp.2011.11.005

BRANCO-DE-ALMEIDA, L. S.; ALVES, C. M.; LOPES, F. F.; PEREIRA, A.F.; GUERRA, R. N.; PEREIRA, A. L. Salivary IgA and periodontal treatment needs in diabetic patients. Braz Oral Res. v. 25, n. 6, p. 550-555, 2011. http://dx.doi.org/10.1590/S1806-83242011000600013

CHANG, P. C.; CHIEN, L. Y.; YEO, J. F.; WANG, Y. P.; CHUNG, M. C.; CHONG, L. Y.; KUO, M. Y.; et al. Progression of periodontal destruction and the roles of advanced glycation end products in experimental diabetes. J Periodontol. v. 84, n. 3, p. 379-388, 2013. https://doi.org/10.1902/jop.2012.120076

DAMODAR, S.; MEHTA, D. S. Effect of scaling and root planning on gingival crevicular fluid level of YKL40 acute phase protein in chronic periodontitis patients with or without type 2 diabetes mellitus: A clinicbiochemical study. J Indian Soc Periodontol, v. 22, n. 1, p. 40-44, 2018. doi: 10.4103/jisp.jisp_95_17

GOGENENI, H.; BUDUNELI, N.; CEYHAN-OZTURK, B.; PINAR, G.;AKCALI, A.; ZELLER, I.; RENAUD, D. E.; SCOTT, D. A.; OZÇAKA, O. Increased infection with key periodontal pathogens during gestacional diabetes mellitus. J Clin Periodontol, v. 42, n. 6, p. 506-512, 2015.

https://doi.org/10.1111/jcpe.12418

GREENBLATT, A. P.; SALAZAR, C. R.; NORTHRIDGE, M. E.; KAPLAN, R. C.; TAYLOR, G. W.; FINLAYSON, T. L.; QI, Q.; BADNER, V. Association of diabetes with tooth loss in Hispanic/Latino adults: findings from the Hispanic community health study/study of latinos. BMJ Open Diabetes Res Care. v. 4, n. 1, p. 1-9, 2016. http://dx.doi.org/10.1136/bmjdrc-2016-000211

GUO, Y.; GUO, L.N.; ZHU, J.F.; TANG, C.Y.; FENG, Y.Z.; ZHOU, H.D. Associations of Salivary BPIFA1 Protein in Chronic Periodontitis Patients with Type 2 Diabetes Mellitus. Int J Endocrinol. 2017;2017:1087017. doi: 10.1155/2017/1087017. https://doi.org/10.1155/2017/1087017

KAKOEI, S.; HOSSEINI, B.; HAGHDOOST, A. A.; SANJARI, M.; GHOLAMHOSSEINIAN, A.; AFSHAR, V. F. Evaluation of Salivary Secretory Immunoglobulin A Levels in Diabetic Patients and Association with 
Oral and Dental Manifestations. Sultan Qaboos Univ Med J. v. 15, n. 4, p. 507-511, 2015. doi: 10.1097/MD.0000000000000292. https://doi.org/10.1097/MD.0000000000000292

KAUR, G.; HOLTFRETER, B.; RATHMANN, W. G.; SCHWAHN, C.; WALLASCHOFSKI, H.; SCHIPF, S.; NAUCK, M.; KOCHER, T. Association between type 1 and type 2 diabetes with periodontal disease and tooth loss. J Clin Periodontol. v. 36, n. 9, p. 765-774, 2009. https://doi.org/10.1111/j.1600-051X.2009.01445.x KIM, N.H.; LEE, G.Y.; PARK, SK.; KIM, Y.J.; LEE, M.Y.; KIM, C.B. Provision of oral hygiene services as a potential method for preventing periodontal disease and control hypertension and diabetes in a community health centre in Korea. Health Soc Care Community, v. 26, n. 3, p.e378-e385, 2018.

https://doi.org/10.1111/hsc.12535

LALLA, E.; PAPAPANOU, P. N. Diabetes mellitus and periodontitis: a tale of two common interrelated diseases. Nat Rev Endocrinol. v. 7, n. 12, p. 738-748, 2012. https://doi.org/10.1038/nrendo.2011.106

LORENTZ, T. C.; COTA, L. O.; CORTELLI, J. R.; VARGAS, A. M.; COSTA, F. O. Prospective study of complier individuals under periodontal maintenance therapy: periodontal parameters, risk predictors and the progression of periodontitis. J Clin Periodontol. v. 36, n. 1, p. 58-67, 2009. https://doi.org/10.1111/j.1600051X.2008.01342.x

MAURI-OBRADORS, E.; MERLOS, A.; ESTRUGO-DEVESA, A.; JANÉ-SALAS, E.; LÓPEZ-LÓPEZ, J.; VIÑAS, M. Benefits of non-surgical periodontal treatment in patients with type 2 diabetes mellitus and chronic periodontitis: A randomized controlled trial. J Clin Periodontol. v. 45, n. 3, p. 345-353, 2018.

https://doi.org/10.1111/jcpe.12858

MOURÃO, L. C.; GARCIA, E.; PASSOS, D.; LORENA, T.; CANABARRO, A. Impact of weel-controlled type 2 diabetes mellitus on quality of life of chronic periodontitis patients. J Indian Soc Periodontol. v. 20, n. 6, p. 623-626, 2016. https://doi.org/10.4103/jisp.jisp_218_16

NASCIMENTO, G. G.; LEITE, F. R. M.; VASTERGAARD, P.; SCHEUTZ, F.; LOPEZ, R. Does diabetes increase the risk of periodontitis? A systematic review meta-regression analysis of longitudinal prospective studies. Acta Diabetol. 2018. https://doi.org/10.1007/s00592-018-1120-4

OIKAWA, J.; UKAWA, S.; OHIRA, H.; KAWAMURA, T.; WAKAI, K.; ANDO, M.; HATA, A.; TAMAKOSHI, A. Diabetes mellitus is associated with low secretion rates of immunoglobulin a in saliva. J Epidemiol. v. 25, n. 7, p. 470-474, 2015. https://doi.org/10.2188/jea.JE20140088

PABISCH. S.; AKABANE, C.; WAGERMAIER. W.; ROSCHGER, A.; OGURA, T.; HYODO, R.; KATAOKA, S.; TOBORI, N.; OKANO, T.; MURAKAMI, S.; FRATZL, P.; WEINKAMER, R. The nanostructure of murine alveolar bone and its changes due to type 2 diabetes. J Struct Biol, v. 196, n. 2, p. 223231, 2016. https://doi.org/10.1016/j.jsb.2016.09.007

RIBEIRO, F. V.; MENDONÇA, A. C.; SANTOS, V. R.; BASTOS, M. F.; FIGUEIREDO, L. C.; DUARTE, P. M. Cytokines and Bone-Related Factors in Systemically Healthy Patients With Chronic Periodontitis and Patients With Type 2 Diabetes and Chronic Periodontitis. J Periodontol. v. 82, n. 8, p. 1187-1196, 2011. https://doi.org/10.1902/jop.2011.100643

SIMPSON, T. C.; WELDON, J. C.; WORTHINGTON, H. V.; NEEDLEMAN, I.; WILD, S.H.; MOLES, D. R.; STEVENSON, B.; FURNESS, S.; IHEOZOR-EJIOFOR, Z. Treatment of periodontal disease for glycaemic control in people with diabetes mellitus. Cochrane Database Syst Rev. v. 6, n. 11, p. 1- 153, 2015. https://doi.org/10.1002/14651858.CD004714.pub3

SKUDUTYTE-RYSSTAD, R.; SLEVOLDEN E.M.; HANSEN, B.F.; SANDYIK, L.; PREUS, H. R. Association between moderate to severe psoriasis and periodontitis in Scandinavian population. BMC Oral Health. v. 26, n. 14, p. 1-9, 2014. https://doi.org/10.1186/1472-6831-14-139 
SOCRANSKY SS. HAFFAJEE AD. The bacterial etiology of destructive periodontal disease: current concepts. J Periodontol. v. 63, n. 4, p. 322-331, 1992. https://doi.org/10.1902/jop.1992.63.4s.322

TELES, R.; TELES, F.; FRIAS-LOPES, J.; PASTER, B.; HAFFAJEE, A. Lesions learned and unlearned in periodontal microbiology. Periodontol 2000. v. 62, n. 1, p. 95-162, 2014. https://doi.org/10.1111/prd.12010

TEKAVEC, M.M.; TEKAVEC, C.D. PSR provides new patient - management tool. Dent Econ. v. 83, n. 4, p. 69-74, 1993.

TSAI, C.; HAYES, C.; TAYLOR, G. W. Glycemic control of type 2 diabetes and severe periodontal disease in the US adult population. Community Dent Oral Epidemiol. v. 30, n. 2, p. 182-192, 2002.

https://doi.org/10.1034/j.1600-0528.2002.300304.x

TSOGNY-TSAGUE, N. F.; LONTCHI-YIMAGOU, E. NANA, A. R. N.; TANKEU, A. T.; KATTE, J.C.; DEHAYEM, M.Y.; BENGONDO, C.M.; SOBNGWI, E. Effects of nonsurgical periodontal treatment glycated haemoglobin on type 2 diabetes patients (PARODIA 1 STUDY): a randomized controlled trial in a sub-saharan Africa population. BMC Oral Health. v. 18, n. 1, p. 2-8, 2018. https://doi.org/10.1186/s12903-018-0479-5

VAN-DER-VELDEN, U. The Dutch periodontal screening index validation and its application in The Netherlands. J Clin Periodontol. v. 36, n. 12, p. 1018-1024, 2009. https://doi.org/10.1111/j.1600-

051X.2009.01495.x

WHANG, T. F.; JEN, I. A.; CHOU, C.; LEI, Y. P. Effects of periodontal therapy on metabolic control in patients with type 2 diabetes mellitus and periodontal disease: a meta-analysis. Medicine (Baltimore). v. 93, n. 28, p. 1-7, 2014. https://doi.org/10.1097/MD.0000000000000292

WOOTON, A. K., MELCHIOR, L. M.; COAN, L. L.; REDDINGTON, A. R. Periodontal disease in children with type 2 diabetes mellitus. Nurse Pract. v. 43, n. 2, p. 30-35, 2018.

https://doi.org/10.1097/01.NPR.0000529666.08823.01

ZAMBON, M.; MANDO, C.; LISSONI, A.; ANELLI, G. M.; NOVIELLI, C.; CARDELLICCHIO, M.; LEONE, R.; MONARI, M. N.; MASSARI, M.; CETIN, I.; ABATI, S. Inflammatory and oxidative responses in pregnancies with obesity and periodontal disease. Reprod Sci 2018 Jan 1: 193371911749.

https://doi.org/10.1177/1933719117749758 